\title{
Rekryteringspolitik vid 1900-talets slut
}

\section{Nya projekt - gamla berättelser}

Våren 1993 bjöd Utbildningsdepartementet in närmare hundra utvalda personer till en idé- och arbetskonferens på Hässelby slott utanför Stockholm. Under två dagar samlades representanter för kommuner, näringsliv, organisationer, universitet och skolväsende för diskussioner under rubriken "Hur kan ungdomars intresse för naturvetenskap och teknik stimuleras?"527 Inför konferensen hade Verket för högskoleservice publicerat en skrift som förmedlade budskap om sjunkande intresse för dessa ämnen och behovet av att skyndsamt vända trender. Dessutom fanns en genomgång av tidigare rekryteringsinitiativ. De läsare som till äventyrs inte var bekanta med problemområdets förflutna kunde där ta del av det omfattande arbete som lagts ned under föregående decennier. Texten gav uttryck för en kraftsamling och påminde på samma gång om att varaktiga lösningar fortfarande saknades. ${ }^{528}$

Bland de som höll något av konferensens arton föredrag återfanns förutom skolminister Beatrice Ask bland annat företrädare för näringslivet, naturvetenskaplig didaktik, science center-rörelsen och Unga Forskare. Dessutom närvarade representanter från andra länder som berättade om hur de handskats med liknande frågor. I mindre grupper utarbetade deltagarna förslag på nya idéer och åtgärder. Arrangemanget avslutades med att utkasten överlämnades till departementet för vidare behandling och beslut. ${ }^{529}$

Bakgrunden till konferensen på Hässelby slott stod framförallt att finna i två händelser som på kort tid uppväckt bilden av ett ökande avstånd mellan utbud och efterfrågan på ingenjörer och naturvetare. För det första hade rapporteringen från industrin - $\mathrm{i}$ ett mönster som stod att känna igen från tidigare perioder - pekat på ett kraftigt växande behov av tekniska utbildningsplatser. Enligt skriften Ingenjörer för 200o-talet, som gavs ut av 
Ingenjörsvetenskapsakademien på uppdrag av Näringslivsdepartementet, krävdes en fördubbling av antalet civilingenjörer fram till år 2010 för att kunna trygga en hög teknisk kompetens och därmed säkra tillväxten och svenska företags konkurrensmöjligheter på en hårdnande marknad. Det ökade behovet av kvalificerade ingenjörer berodde på att situationen inte längre kunde mötas med enklare produktion eller tätare personalbesättning. Lösningen låg i en "förädling av kunskapsbasen", där vidareutbildning inom industrin var en viktig del, men också ökad intagning vid de tekniska högskolorna och väsentligt ökad rekrytering till gymnasierna. Ingenjörsvetenskapsakademien pekade även på att rekryteringen behövde fortsätta till högre nivåer. Framförallt var det den industriorienterade och tillämpade tekniska forskningen vid högskolorna som var i behov av en fördubbling till år 2000. ${ }^{530}$ Ingenjörer för 2000-talet skulle senare under 1990-talet följas av andra publikationer som bekräftade denna bild. ${ }^{531}$

För det andra visade siffror från Utbildningsdepartementet att antalet sökande till teknisk linje på gymnasiet sjunkit under 1990-talets första år. Trots att trenden var kortsiktig framställdes situationen som i behov av omedelbara åtgärder. ${ }^{532}$ I sin utbildningsproposition deklarerade därför den nytillträdda borgerliga regeringen att det var "av största vikt" med åtgärder som ökade söktrycket från grundskolan till naturvetenskapliga och tekniska studievägar i gymnasiet. ${ }^{533}$

Enligt den lägesbeskrivning som tecknades var barns och ungdomars förhållande till naturvetenskap och teknik mer problematiskt än på flera år. En sådan bild grundlades inte minst av det återkommande talet om deras "minskande" eller "vikande" intresse för dessa utbildningar. Tillsammans med formuleringar om att "vända trenden" förstärkte ordvalen en bild av ungdomars återkommande benägenhet att söka sig bort från dessa ämnen. ${ }^{534}$

Det var sådana krav på skyndsam aktion som Hässelbykonferensen 1993 avsåg att möta. När de ansvariga för sammankomsten överlämnade sina förslag på åtgärder och nya idéer innebar detta att initiativet återfördes till regeringen. Resultaten visade sig redan några månader senare när Utbildningsdepartementet presenterade NOT-projektet (naturvetenskap och teknik) med syfte att "vidareföra och initiera åtgärder inom skolans och den högre utbildningens område som syftar till att öka ungdomars intresse och förutsättningar för studier med teknisk och naturvetenskaplig profil" "535 Projektet var långsiktigt och skulle komma att bedrivas i två omgångar över sammanlagt tio års tid under ledning av Skolverket (tidigare Skolöverstyrelsen) och Verket för högskoleservice (senare Högskoleverket). ${ }^{536}$ 
Betraktat ur en innehållslig synvinkel var NOT-projektet snarast en förvaltare av tidigare traditioner för enrollering av naturvetare och ingenjörer. I presentationer av hur man såg på motiven för sådana utbildningar märktes bara argument som funnits med länge:

Det finns många skäl att stimulera intresset för naturvetenskap och teknik. Eftersom vi tar stora kliv in i kunskapssamhället vill näringslivet ha välutbildad arbetskraft. Sveriges beroende av omvärlden ökar, vårt näringsliv måste hävda sig på en arbetsmarknad - vilket också kräver ökade kunskaper. Högskolor och andra forskningscentra är angelägna om att hitta intresserade studenter. Politikerna är i sin tur intresserade av att förse både näringsliv och forskning med människor som kan föra Sverige framåt som kunskapsnation. Som medborgare i ett demokratiskt samhälle förväntas vi också ha en bas av naturvetenskapliga och tekniska kunskaper. För en allsidig utveckling behövs dessutom fler kvinnor inom naturvetenskap och teknik. Tillsammans utgör dessa behov motivet för NOT-projektets arbete. ${ }^{537}$

Det var snarare till formen som den nya satsningen var en rekryteringspolitisk innovation. Även om NOT-projektet påminde om hur N-gruppen under 1970-talet hade formaliserat utbytet mellan rekryteringsdiskursens talare och publiker, var magnituden ojämförligt mycket större denna gång. Genom återkommande publikationer skapades en fast och medialt inarbetad struktur som gav spridningen av problembilden en helt annan räckvidd än två decennier tidigare. Förutom en bok (NOT-boken) och en skrift (Notskriften) producerades också en rapportserie innehållande drygt tjugo så kallade NOT-häften där forskning och information om rekryteringsprojekt presenterades. I dessa texter sammanställdes också ny kunskap om elevers förhållande och attityder till naturvetenskap och teknik. Med hjälp av intervjuer, statistiska översikter och jämförelser med andra länder ackumulerades ett vetande som sedan användes i andra sammanhang. Utöver detta spreds varannan månad NOT-bladet med ständiga uppdateringar över olika initiativ nationellt och lokalt. Den åttasidiga informationstexten var gratis och hade som mest en upplaga på 18000 exemplar. ${ }^{538}$

I högre grad än tidigare satsningar bestämdes också att NOT-projektet skulle "försöka påverka barn och ungdomar via vuxna i deras närhet". ${ }^{539}$ Därför identifierades lärare, politiker och rektorer som en viktig målgrupp. För att skapa möjligheter till utbyte mellan dessa yrkesgrupper prioriterades 
genomförandet av konferenser på såväl nationell som regional och lokal nivå. ${ }^{540}$ Förhoppningen var att dessa tillfällen skulle etablera nätverk där idéer och initiativ kunde spridas. Arbetet med att bygga upp den lokala infrastrukturen för rekrytering till naturvetenskap och teknik tog sig också uttryck i etablerandet av speciella NOT-kommuner där undervisningen i ämnena skulle ges särskild uppmärksamhet. ${ }^{541}$

NOT-bladet rapporterade under hela 1990-talet om en livlig lokal rekryteringsaktivitet. Det framkom också att många av metoderna var redan beprövade idéer från tidigare decennier. Således fortsatte försöken med att anordna sommarkurser i teknik för flickor liksom fadderverksamhet där forskare berättade om sina spännande projekt för att inspirera elever i gymnasier och grundskolor. ${ }^{542}$ Science center-rörelsen expanderade ute i landet med lokalt profilerade utställningar. Till exempel slog Molekylverkstan i Stenungsund upp sina portar 1993 i ett samarbete mellan statliga myndigheter och sju lokala företag inom den petrokemiska industrin. Syftet var att intressera barn och unga för naturvetenskap och teknik men också att i förlängningen kunna rekrytera välutbildad personal till de närliggande företagen..$^{543}$

NOT-projektet var den största satsningen på att lösa rekryteringsproblemet under perioden, men det fanns fler aktörer som engagerade sig i frågan. När Sveriges Naturvetareförbund lanserade initiativet Naturvetarna och framtiden utgick de från den bild som etablerats av en ökande klyfta mellan samhället och ungdomsgenerationerna ifråga om inställningen till naturvetenskap och teknik. I en debattskrift räknade förbundet upp flera förslag på åtgärder som skulle förbättra undervisningen, tidigt sätta elever i kontakt med naturvetenskap och höja lärarlönerna i syfte att förbättra yrkets status. Dessutom föreslog de en större satsning på samverkan mellan universiteten och näringslivet i frågan..$^{54}$ Debattskriften visade att opinionsbildningen inte enbart var avhängig regeringens propositioner och näringslivets prognoser utan även upprätthölls av mindre aktörer.

\section{Det naturvetenskapligt-tekniska basåret}

I utbildningspropositionen 1993 skrev ansvarige statsrådet Per Unckel:

Flertalet av de elever som en gång valt en viss utbildningsväg brukar inte byta bana. Ett snabbt ökat intresse för de naturvetenskapliga och tekniska utbildningsområdena i gymnasieskolan förbättrar därför 
möjligheterna att också uppnå en snabbare ökning av examinationen från de högre utbildningar som näringslivet efterfrågar.

Samtidigt uttrycktes det i samma text just en önskan om att fler individer som istället valt bort naturvetenskapliga och tekniska utbildningar skulle ändra sig och "byta bana". ${ }^{545}$ För att uppnå en sådan utveckling hade den borgerliga regeringen sjösatt en nationell satsning kallad basåret, en kompletterande ettårig utbildning på gymnasienivå i matematik, fysik och kemi. Kursen bedömdes motsvara vad som lärdes ut vid de naturvetenskapliga och tekniska gymnasielinjerna och gav behörighet att läsa vidare inom dessa ämnen på högskolenivå. ${ }^{546}$

Strategin bakom basåret var att i stor skala söka identifiera och nå de personer som redan valt studieväg i syfte att förmå dem att byta inriktning. Utgångspunkterna kan betraktas som att ett stort antal ungdomar bedömdes ha valt fel utbildning beträffande såväl deras egna framtidsutsikter som samhällets bästa. Det tidiga 1990-talet uppfattades vara präglat av en kombination av hög arbetslöshet och samtidigt ett stort behov av framförallt civilingenjörer. Därför vägleddes idén om basåret av en strävan att inte bara göra människor behöriga utan också få dem att korrigera synen på sig själva och handla i enlighet med rekryteringspolitikens bild av situationen. Som enrolleringspraktik var utbildningen således avsedd att fungera som ett slags omvänd "naturvetarflykt" - att omskola, reformera eller konvertera ett stort antal av de identifierade individerna till tekniska och naturvetenskapliga yrken och identiteter.

Ett av de huvuduppdrag som regeringen gav till NOT-projektet under 1990-talet var att följa upp och kontinuerligt utvärdera basåret. Flera av de rapporter som projektet producerade ägnades åt att utreda vilken effekt dessa satsningar hade på rekrytering till högre nivå. ${ }^{547}$ I likhet med 1950-talets stora universitetsutredning fanns dock en underliggande retorisk fråga om hur många som egentligen hade fallenhet för de ämnen som var aktuella. Vilka var det överhuvudtaget någon idé att tilltala?

Som vi tidigare konstaterat användes under den tidiga efterkrigstiden uttrycket tekniskt-naturvetenskapliga "reserver" för att ringa in den avsedda målgruppen. I sin utredning 1958 hade Kjell Härnqvist breddat den andel av befolkningen som ansågs lämplig för sådana studier. År 1995 - nästan 40 år senare - genomförde Härnqvists yngre kollega Allan Svensson, docent i pedagogik, en undersökning med liknande syfte. På uppdrag av NOT-projektet sökte han identifiera elever "som har goda förutsättningar att klara av naturvetenskapliga och tekniska studier, men 


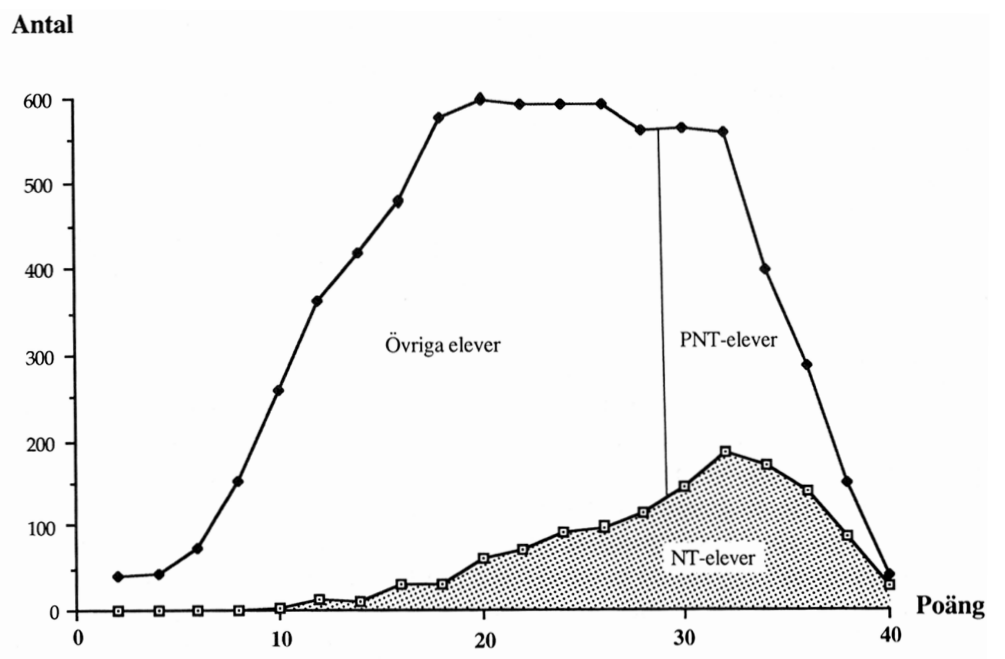

Poängfördelningen $i$ det logiskt-induktiva testet för olika elevkategorier.

Bild 22. Pedagogen Allan Svenssons studie identifierade de så kallade "PNT-eleverna" som högintressanta för rekryteringsåtgärder. (Bildkälla: Svensson, 1995)

som trots detta inte skaffar sig en sådan utbildning". ${ }^{48}$ Med "goda förutsättningar" menades i första hand matematisk förmåga. Genom resultatet på logiskt-induktiva tester i grundskolans sjätte klass identifierades rätt sorts individer - så kallade "PNT-elever" ("potentiella naturvetenskapliga och tekniska elever"). Resultatet inom en årskull född 1972 jämfördes med valen av utbildning till gymnasiet. Bland de som nått över ett visst antal poäng på testet men inte sökt naturvetenskap och teknik fanns de ur rekryteringspolitisk synvinkel mest intressanta. ${ }^{549}$

Precis som Härnqvists utredning om begåvningsreserven gav Svenssons undersökning en vetenskaplig grund för initiativ som basåret. Utifrån sin undersökning uppskattade författaren att "ett betydande antal ungdomar, varierande mellan tio och tjugo tusen per årskull" hade förutsättningar för att kunna genomföra sådana studier. ${ }^{550}$

I strategierna för hur basåret skulle utformas fanns också erfarenheter från tidigare lokala försök. Vid både Uppsala universitet och Högskolan i Luleå hade man sedan slutet av 1970-talet anordnat liknande utbildningar med något olika profiler. Vid den senare hade man i första hand riktat sig till elever vid samhällsvetenskapliga och ekonomiska gymnasielinjer i de fyra nordligaste länen samt Stockholms län. ${ }^{551}$ Till dessa skickades 
information om ett tekniskt basår. Tilltalet utformades på många sätt som en uppmaning till personerna att ompröva sig själva och sina livsval:

Fånga tillfället i flykten - För dig som gått E -eller S-linjen på gymnasiet. Framtidsjobben finns inom de tekniska yrkena - det är alla överens om. En mångfald vägar står öppna för den som har teknisk utbildning. Men det är nästan bara de elever som gått naturvetenskaplig eller teknisk linje på gymnasiet som kan välja teknisk högskoleutbildning. Den som valt "fel" linje måste i allmänhet komplettera sina ämnen och det tar tid. ${ }^{552}$

Reklammaterialet dominerades av livsberättelser från de teknikens konvertiter som redan lämnat ekonomiska och samhällsvetenskapliga utbildningar för att läsa i Luleå. Deras historier om vägen till ingenjörsyrket underströk hur tidigare "felval" kunde vändas till mer fördelaktiga beslut, liksom den roll som informationskampanjerna hade spelat. ${ }^{553}$

Det var också uppenbart att det tekniska basårets utformning bar spår av den mer lokalt präglade rekryteringspolitik som legat bakom uppförandet av Teknikens Hus. Utbildningen knöts i första hand till fortsatta studier i Luleå. "Kurserna du läser är anpassade till den fortsatta utbildningen vid Högskolan i Luleå. Efter det tekniska basåret är du garanterad en plats på någon av de tekniska utbildningslinjerna just vid Högskolan i Luleå." 554

När basåret lanserades i full skala över hela Sverige 1992 var det ett av många uttryck för att rekryteringspolitikens liberala styre hade en befolkningspolitisk inriktning. Stora mängder människor i övergången till vuxenlivet mottog uppmaningen att göra om sina val av karriär. Basåret erbjöds vid 26 högskolor och universitet och informationsmaterialet delades ut till landets samtliga 24000 gymnasieelever vid de samhällsvetenskapliga och ekonomiska linjerna. Även värnpliktiga som tidigare gått dessa linjer erhöll brev med informationen, liksom ytterligare 20000 personer i Centrala antagningsenhetens register. Information skickades också till samtliga landets 5000 syofunktionärer. Därutöver innefattade kampanjen reklam i dagstidningar och på tv..$^{555}$

Det utskickade materialet presenterade basåret som ett "kliv mot nya möjligheter" och ackompanjerades av tidigare studenters uttalanden om ökad läslust och stärkt självkänsla. I en situation när framtidsperspektiven på den svenska arbetsmarknaden i övrigt talade om kraftigt ökande 
arbetslöshet, svag tillväxt och fåtaliga investeringar i industrin, laddades naturvetenskapliga och tekniska utbildningar med löften om goda utsikter till kvalificerade och meningsfulla framtidsyrken. ${ }^{556}$

\section{Frigörande utbildningar}

Som rekryteringspolitisk satsning uppfattades basåret som "mycket lyckad". I mitten av 1990-talet uppgick det sammantagna antalet studenter inom utbildningen till 3600 . De positiva uttalandena gjordes särskilt med avseende på att andelen kvinnor var högre på basåret än på traditionella naturvetenskapliga och tekniska utbildningsvägar. ${ }^{57}$ Mot bakgrund av det goda utfallet förlängdes utbildningen under hela 1990-talet. Den socialdemokratiska regering som tog över makten 1994 kom därmed att vidarebefordra både NOT-projektet och basåret. Härmed bekräftades den partipolitiska konsensus som många år tidigare etablerats i Sverige när det gällde naturvetenskaplig och teknisk rekrytering. Dessutom vidgades basåret till att ges även på Komvux. Då riktade det sig till delvis andra målgrupper som riskerade att hamna i arbetslöshet eller redan stod utanför arbetsmarknaden. I denna form var erbjudandet om obligatorisk plats vid högskolan indraget. Istället lockade flera kommuner med andra attraktionskomponenter i form av stipendier på $10000 \mathrm{kr}$ per person att utbetalas vid helt genomgången utbildning. ${ }^{558}$

Ekonomiska belöningar för att välja naturvetenskap och teknik hade inte tidigare prövats i någon större utsträckning. Men idén gavs utrymme i ytterligare en satsning mellan 1995 och 1998. Utbildningen N/T-SVUX riktade sig till personer i åldrarna 25-48 och var en komplett högskoleutbildning inom teknik eller naturvetenskap med ekonomisk ersättning under tiden. Tanken var att dessa satsningar kunde nå nya målgrupper, bland annat personer som hade tidigare arbetslivserfarenhet men saknade utbildning på högskolenivå. Om de saknade gymnasiekompetens inom dessa ämnen kunde de även få en sådan utbildning med ekonomiskt fördelaktiga villkor. Sammanlagt påbörjade 9000 människor N/T-SVUX. ${ }^{559}$

Finansieringen utökade den repertoar av argument och påverkansfaktorer som användes i kampanjerna. Reklammaterialet utropade: "Nu kan du mellan 27-48 år utbilda dig till Civilingenjör, Ingenjör, Naturvetare, Lärare med NO-inriktning - och få betalt under tiden!" ${ }^{60}$ Den ekonomiska ersättningen blev - vid sidan av löften om en ljus arbetsmarknad, ett meningsfullt yrke och en i de flesta fall god löneutveckling - ytterligare en 


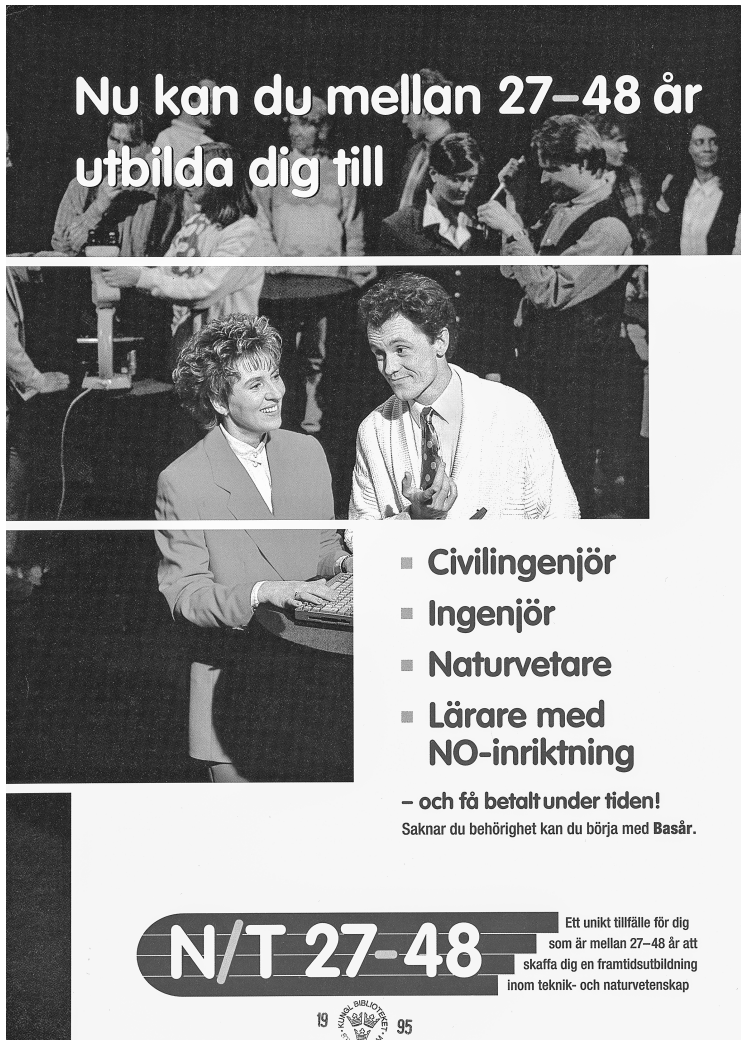

Bild 23. Reklamkampanj för N/T-SVUX. (Foto: okänd/Verket för högskoleservice/ Kungliga biblioteket)

komponent i den positiva maktutövning som kunde generera självstyre mot naturvetenskap och teknik. Många av de som började på utbildningen uppgav just det ekonomiska bidraget som en avgörande orsak, framförallt personer som annars inte tänkt läsa vidare överhuvudtaget. I rapporter vittnade flera N/T-SVUX-elever om pågående processer där identiteter omförhandlades och där omskolningen till naturvetare eller ingenjör också innebar förvärvandet av ett utbildningskapital:

Jag hade länge längtat efter att få studera matematik, men var rädd för att ta lån. När denna möjlighet yppade sig (som dessutom vände sig till min åldersgrupp) vågade jag ta steget. Jag riskerade då att bli arbetslös - och har också blivit det under utbildningen. Jag ångrar inte 
att jag började studera - det är mycket intressant och stimulerande - och nu vet jag inte längre varför jag var så rädd för att ta studielån. Men det kanske delvis beror på att vi inte har någon studietradition i min familj. (Jag kommer från ett arbetarhem). ${ }^{561}$

Det stora antalet personer som valde att "ta steget" innebar att kampanjer som basåret och N/T-SVUX kunde framställas som framgångsrika. Den kollektivt genomförda reformeringen var möjlig att förstå som nyttig både i ett samhälleligt och individuellt hänseende. Medan behovet av fler naturvetare och ingenjörer hade tillgodosetts på ett nationellt plan, kunde beslutet att välja dessa ämnen för enskilda personer förstås som en allmän form av kompetenshöjning, ett tillfälle att byta karriär eller inledning på en klassresa. De hade getts "en andra chans" att läsa ämnena och därmed möjligheten att korrigera ett både personligt och samhälleligt felval. ${ }^{562}$

\section{Valfrihet, vetenskap och rekryteringspolitikens etik}

Även om vi i tidigare kapitel konstaterat att termen valfrihet - både i retorisk mening och som utbildningspolitiskt instrument - brukades vid återkommande tillfällen redan under 1960-talet, är det tydligt att den skulle komma att inta en mycket mer central position som ideologiskt underlag för reformer under 1900-talets sista decennium. Mellan åren 1991 och 1994 beslutade den borgerliga regeringen att på skolområdet ge större utrymme åt individens självbestämmande, dels genom att ge möjlighet att starta och driva fristående skolor, dels genom att låta elever och föräldrar välja mellan fristående eller kommunala skolor. Detta skedde framförallt genom att knyta en så kallad "skolpeng" till varje elev. ${ }^{563}$

En liknande förändring initierades även inom den högre utbildningen. I den borgerliga regeringens högskoleproposition Högre utbildning för ökad kompetens presenterades 1993 en "studentpeng" i syfte att ge studenternas val av lärosäten och efterfrågan på studieinriktning större konsekvenser för universitetens framtida resurstilldelning. Som en följd skulle ekonomiska medel till varje lärosäte betalas ut i form av per capita-ersättning för varje student i olika ämnen. ${ }^{564}$

Inom utbildningsvetenskaplig forskning har man beskrivit ovanstående valfrihetsreformer som uttryck för ett "systemskifte", kännetecknat av en tydlig övergång från statligt utförd välfärdspolitik, i såväl Sverige som utomlands, till en marknadifiering och ett förverkligande av mer 
nyliberala idéer. ${ }^{565}$ I relation till den parallellt pågående rekryteringspolitiken är det möjligt att identifiera hur denna nyskapade utbildningsmarknad fick konsekvenser som - återigen - underströk problemet med att söka främja det fria valet av utbildning å ena sidan och att acceptera konsekvenserna av sådana val å den andra. På ett retoriskt plan var det uppenbart att kampanjerna tillhörande basåret och N/T-SVUX förmedlade ett budskap som tog plats i den nya utbildningspolitiska diskursen; talet om ökade möjligheter, "öppnade dörrar" och breddad kompetens knöt an till den nyliberala idén om större valfrihet. Att betona dessa två utbildningars betydelse för ökad behörighet påminde dessutom om den formella exklusivitet som hade omgett just naturvetenskapliga studier sedan skapandet av "kungsleden" på 1960-talet.

På ett annat plan skulle det emellertid visa sig att rekryteringsåtgärderna till sin praktiska utformning också kunde utmana idén om frihet i förhållande till utbildning. Bara några år efter studentpengens införande skulle staten - nu i form av en socialdemokratisk regering - inskärpa hur viktigt det var att 1990-talets studenter förstod att välja just naturvetenskapliga och tekniska studieinriktningar. I en utbyggnad av den högre utbildningen med 30000 permanenta platser öronmärktes hälften av dessa åt naturvetenskap och teknik för "att tillgodose näringslivets behov av hög kompetens". ${ }^{566}$ För att säkerställa att en sådan fördelning efterlevdes fastställdes bland annat miniminivåer för antalet helårsstudenter vid respektive lärosäte inom dessa discipliner - en prioritering som ledde till att många högskolor kraftigt förändrade sina utbildningsprofiler och i större omfattning än tidigare sökte inrikta sitt utbud mot ingenjörs- och naturvetarutbildningar. ${ }^{567}$

Försöken att påverka individens val gick således genom en starkare styrning av högskolans utbildningsutbud. Mellan 1994/95 och 1999 ökade andelen helårstudenter inom naturvetenskapliga ämnen med 38 procent i landet, vilket motsvarade drygt 10000 personer. ${ }^{568}$ Ändå beskrev många lärosäten det som problematiskt att nå målen då de hade begränsade möjligheter att påverka rekryteringen när studenterna redan hade lämnat gymnasiet. ${ }^{569}$

Regleringen av en utbildningsmarknad som i övrigt omgavs av höga ambitioner när det gällde hänsyn till valfrihet och efterfrågan, är ett tydligt exempel på kollisionen mellan de utbildningspolitiska ambitioner som varit ett genomgående tema i denna bok. När det gäller tidigare decennier har vi kunnat konstatera att sådana uppenbara modifieringar i en valfrihetsbaserad politik ledde till olika former av markeringar som 
förtydligade gränserna för rekryteringspolitikens handlingsutrymme. Så var det i samband med försöken att stoppa "Na-flykten" i slutet av 1960-talet, och med TEK-NA-projektet ett knappt decennium senare. Fördes det även någon principiell diskussion om påverkan och utbildningspropaganda under 1900-talets sista årtionde?

I ett undantag mot en annars så partipolitiskt konsensusartad diskussion gjorde kristdemokraterna en principiell markering $1996 \mathrm{i}$ en riksdagsmotion mot regeringens beslut om starkare styrning. Partiet framhöll i ett resonemang om "humanioras roll" att en satsning på naturvetenskap och teknik visserligen var "fullt berättigad". ${ }^{570}$ Samtidigt ville man påpeka följande:

Det går dock inte att ensidigt prioritera teknik och naturvetenskap. Många av högskolans kunskapsområden saknar helt eller delvis kommersiellt intresse. Utbildning och forskning inom dessa områden måste bedrivas av andra skäl och med andra förtecken än industriell förnyelse eller regional utveckling. [...] Regeringen menar att universiteten och högskolorna bör anpassa utbildningsutbudets inriktning till områden där behovet av välutbildad arbetskraft förväntas öka. Detta kan vid en första anblick verka förnuftigt, men kristdemokraterna anser att även studenternas efterfrågan skall styra utbildningsbehovet. ${ }^{571}$

Frågan om varför just naturvetenskap och teknik borde prioriteras så kraftigt berördes också i ett annat sammanhang. I sin utredning om de tidigare omnämnda "PNT-eleverna" ifrågasatte den för NOT-projektet anlitade pedagogen Allan Svensson vid ett tillfälle de etiska utgångspunkterna för rekryteringspolitiken:

Är det försvarbart att försöka förmå merparten av de ungdomar som har goda studieförutsättningar för matematik att satsa på en teknisk eller naturvetenskaplig gymnasial utbildning? Många av dessa ungdomar torde även ha goda förutsättningar för andra studieinriktningar. Skall de humanistiska, ekonomiska och samhällsvetenskapliga utbildningarna "dräneras" på begåvningar? Behöver samhället inte begåvade människor också inom de yrken som dessa studier syftar till? Hur går det med individens fria rätt att välja utbildning och yrke? ${ }^{572}$

Uttalandet snuddade vid de tidigare decenniernas uppkomna konflikter om var gränserna för styrning av individer gick inom ramarna för det 
demokratiska samhällets självbild. I ett kortfattat svar på sin egen fråga påpekade Svensson att en relativt stor andel av "PNT-eleverna" inte läste vidare på andra teoretiska utbildningar. I den mån de överhuvudtaget sökte sig till gymnasiet valde de praktiska linjer. Den eventuella dräneringen av begåvningar från humaniora och samhällsvetenskap kunde mot den bakgrunden inte betecknas som särskilt omfattande. ${ }^{573}$

Svenssons egen bedömning blev dock det enda inlägget i frågan. Vare sig NOT-projektet, Utbildningsdepartementet eller någon annan aktör gav den typen av principiella spörsmål något utrymme i den omfattande produktionen av rapporter, promemorior och utredningar i ärendet. Således bedömdes rekryteringsfrågan inte rymma någon tillräckligt försvårande etisk komponent under perioden, där explicita överväganden mellan propaganda, resurstilldelning och självbestämmande var nödvändiga för att legitimera politiska beslut.

\section{Ett problem med särskilt svenska förtecken}

Diskussionen om antalet individer inom naturvetenskap och teknik hade redan under efterkrigstidens första decennier - och längre tillbaka än så omgärdats av nationella förtecken. Mängden individer med "rätt" utbildning och yrkesprofil gjordes i flera sammanhang till ett mått på kvaliteten inom ett utbildningssystem. ${ }^{574}$ I varierande grad skulle dessa perspektiv bidra till att upprätthålla oron för att falla tillbaka i jämförelse med andra länder. Ofta fanns de ekonomiska utsikterna i förgrunden när bruket av nationella perspektiv blev särskilt uttalade. Det gjorde att andra argument för fler naturvetare och ingenjörer - jämställdhet, miljöhänsyn och medborgerlig vetenskaplig bildning - i perioder hamnade i bakgrunden.

De första åren av 1990-talet var en sådan period. Näringslivets uppfattning om ett hårdnande internationellt klimat förstärkte behovet av att tala om Sveriges position i ekonomiska och industriella termer. "Svenskt näringsliv måste ständigt utvecklas för att möta den alltmer accentuerade konkurrensen på världsmarknaden. [...] Vi står i Sverige inför ett val. Är vi villiga att göra de närings- och utbildningspolitiska satsningar som krävs för att aktivt medverka i den internationella marknadsutvecklingen?"575

Det nationella anslaget märktes också i arbeten som föregrep Hässelbykonferensen och NOT-projektet. Enligt en rapport med titeln Naturvetenskap och teknik $i$ Sverige gjorde rekryteringsproblemets återkommande karaktär att det behövdes ett långsiktigt program som nådde hela landet. 
Att öka intresset för naturvetenskap och teknik formulerades som en "nationell uppgift", som krävde att organisationer, myndigheter och andra aktörer samverkade för att nå en mer varaktig effekt:

En framgångsrik framtida utveckling för Sverige och svenska folket bygger på att tillräckligt många vill ägna sig åt naturvetenskap och teknik. Hur kan vi nå det målet? För det första skall vi se till att alla i Sverige känner till behovet av naturvetare och tekniker. Vi skall visa det övertydligt för alla. ${ }^{576}$

Regeringens texter talade samma språk, inte minst genom ständiga jämförelser med andra länder. I sin regeringsförklaring 1991 hade statsminister Carl Bildt talat om att Sverige skulle vara en kunskapsnation med målet att "skapa Europas bästa skola" under decenniet. ${ }^{577}$ När Utbildningsdepartementet formulerade sitt uppdrag till NOT-projektet skrev man: "Ett mål för utbildningspolitiken är nu att med förstärkt kvalitet föra upp universitetens och högskolornas utbildningsvolymer till minst samma nivå som i jämförbara industriländer. Samtidigt skall Sveriges konkurrensförmåga gentemot utlandet stärkas. Här har de tekniska och naturvetenskapliga utbildningarna en nyckeluppgift." ${ }^{578}$ Även från dem som var verksamma i science center-rörelsen var budskapet tydligt. Initiativtagaren till Teknikens Hus, AnnMarie Israelsson, kommenterade Sveriges internationella position:

Det mesta tycks visa på att vi befinner oss långt nere i rangordningen bland Europas eller världens länder. Det kan gälla andelen högskoleutbildade generellt, andelen forskarutbildade, våra skolbarns prestationer i olika ämnen, industrins benägenhet att anställa högutbildade eller något annat som går att mäta och redovisa i tabeller och diagram. Naturvetenskap och teknik är i strykklass i Sverige i mer än ett avseende. ${ }^{579}$

Men de internationella jämförelserna visade sig efter hand ge en allt annat än entydig bild. Flera uppgifter fick situationen i Sverige att framstå som bättre än i andra länder. I en studie av det norska institutet NIFU jämfördes exempelvis de nordiska länderna. Här påtalade man bland annat:

I Sverige har den samlede studentbestand innen MNT-fag økt både i absolutte tal og som relativ andel av den totale studentbestand. Veksten 
gør seg gjeldende både for naturvitenskap-, ingenjør- og sivilingenjørutdanningene. [...] Det er i Sverige en utbredt bekymring for situasjonen på MNT-området. Til tross for ekspansjonen er økningen ikke stor nok for å tilfredsstille behovene i samfunnet framover, hevdes det. ${ }^{580}$

En oberoende utvärdering av NOT-projektet påtalade också att Norge och Danmark hade haft ett sämre utgångsläge i början av 1990-talet när det gällde dessa utbildningar, men trots det inte inlett några motsvarande satsningar på storskalig rekrytering. Utredaren Svein Sjøberg, naturvetenskapsdidaktiker vid Oslo universitet, beskrev NOT-projektets utgångspunkter och åtgärder som sprungna ur "forhold som kanskje kan sies å vare 'typisk svenske"' ${ }^{581}$ Vad han syftade på var framförallt kombinationen av en god tillgång till statistik och prognoser samt en tilltro till rationalitet och planering. ${ }^{52}$

Sjøbergs anmärkningar var måhända också påverkade av den utförliga dokumentation som följde NOT-projektet, liksom den omfattande spridningen av resultaten. Anmärkningen om det "typiskt svenska" kan utvecklas ytterligare för att förstå inte bara NOT-projektet utan även formandet av hela rekryteringspolitiken under efterkrigstiden. Fanns det i Sverige en specifik laddning i frågan om ungdomars intresse för naturvetenskap och teknik? Blev elevers upplevda bortval av dessa utbildningar därför ett särskilt stort problem att brottas med och lösa? Frågorna tydliggör behovet av att förstå vilken roll nationella eller kollektiva identiteter spelade i sammanhanget. Ovan har jag berört de många internationella jämförelser som gjordes. Till dem skall vi återkomma. Men det är också nödvändigt att beakta den jämförelse Sverige gjorde med sin egen historiskt rotade självbild.

\section{Omförhandlingen av nationella självbilder}

I den borgerliga regeringens utbildningsproposition 1993 ramades bristen på civilingenjörer in genom följande formulering:

Svensk industri har historiskt gynnats av ett kvalificerat tekniskt kunnande som bland annat resulterat $i$ en internationellt framgångsrik teknikutveckling och en rad avancerade uppfinningar. Detta har bidragit till att ge Sverige en ledande ställning på världsmarknaden inom flera områden. Idag är vi - bl.a. på grund av otillräckliga satsningar på högre utbildning under 1970- och 80-talen - på väg att halka efter. ${ }^{583}$ 
Texten förmedlade tankegods ur en sekelgammal berättelse om Sverige som en framstående teknik- och vetenskapsnation. Detta narrativ formades under en period då nationsbyggande processer i ökande utsträckning kom att ske genom kulturella och vetenskapliga förtecken snarare än enbart militära. Under de sista decennierna av 1800-talet sågs vetenskapsmännen framträda i andra roller än tidigare. De uppträdde på den offentliga scenen som rikets heroer och engagerades härigenom i den komplexa väv av historiebruk, kulturell nationalism och politik som vid den tiden präglade många av Europas stater. I denna anda växte också tron på en särskild svensk fallenhet för naturvetenskaplig och teknisk verksamhet, påvisad genom bland annat framgångsrika forskningsexpeditioner och vetenskapliga upptäckter. ${ }^{54}$

I framskrivandet av denna berättelse enrollerades framstående men avlidna vetenskapsmän som Carl Wilhelm Scheele, Jöns Jacob Berzelius och Carl von Linné, vilka ansågs ha burit Sveriges rykte vida över världen. ${ }^{55}$ Vad beträffade Linné kunde man, som Uppsalastatistikern Gustav Sundbärg gjorde 1911, knyta det enskilda geniets framgång till tanken på en nationalkaraktär bevisad genom det svenska folkets kärlek till naturen. Enligt en sådan logik hade Linnés vetenskapliga värv befäst ett ursprungligt lynne och samtidigt visat vägen för kommande generationer. ${ }^{586}$ Tankegods av den typen hade under lång tid bidragit till att konsolidera den linneanska traditionen vid landets olika utbildningsinstitutioner, inte minst vid läroverken där botaniken hade en given plats på schemat även om de humanistiska ämnena under lång tid dominerade lärostoffet. ${ }^{587}$

När latinet efter hand utmanades och krav på reformer framfördes var det dock inte under växtsystematikens fana. Istället lyftes det moderna biologiämnet fram tillsammans med kemi och fysik. Inte sällan ackompanjerades dessa reformkrav av tanken att svenskar var särskilt naturvetenskapligt begåvade. ${ }^{58} \mathrm{En}$ av de mer offentliga företrädarna för denna åsikt var Gerard De Geer, geolog och tillika rektor för Stockholms högskola. I en debatt om läroverkens undervisning 1904 framförde han i en andrakammarmotion:

Man har på goda grunder ansett, att svenskarna äga särskild fallenhet för studiet af naturen och för dess tekniska tillämpningar, och otvifvelaktigt är ju äfven, att vi äga ganska många världsberömda namn inom dessa områden, men däremot rätt få inom andra. Nog vore det under sådana förhållanden besynnerligt, om man hos oss, i stället för 
att särskildt uppmuntra och med all möjlig omsorg utveckla sådana anlag, skulle fortfarande bibehålla det slags undervisning, som stått oförstående och ogillande gent emot snillen sådana som Linné och Berzelius. ${ }^{589}$

Liknande argument framfördes av fysiklektorn Tom Moll, sedermera undervisningsråd i Läroverksöverstyrelsen:

I sammanhang härmed må uttalas en mening, som torde vara riktig, ehuru naturligtvis svår att bevisa, nämligen den att naturvetenskapliga studier ligga särskildt väl till för svenska gossar, liksom själfständigt naturvetenskapligt arbete för svenska män. Om det är något område, där den svenska nationen särskildt utmärker sig, så är det inom de exakta vetenskaperna och deras tillämpningar. Sverige har haft ett ganska stort antal världsberömda naturforskare och framstående ingenjörer. Hur många filosofer, teologer, filologer, historici har det haft af motsvarande rang? ${ }^{290}$

Både De Geer och Moll inkluderade således ingenjörstypen och den tekniska kompetensen i sina framställningar. Hyllandet av det industriella geniet och entreprenören var kanske ett än tydligare drag i denna idétradition; uppfinnare som Gustaf de Laval, John Ericsson och Gustaf Dalén anfördes alla under de första decennierna av 1900-talet som utslag av en nationell fallenhet för ingenjörskonst och entreprenörsanda. ${ }^{591}$

Snillemyten begränsade sig dock inte till enskilda individer. Även de företag och industrier som så småningom förknippades med personerna antogs uttrycka svenska särdrag. Så kunde framgångsrika bolag som L.M. Ericsson, ASEA, AGA, Separator, SKF och deras respektive exportprodukter antas vara tecken på en nationell "begåvningsinriktning". ${ }^{52}$ Gerard De Geers yngre släkting och namne skulle under 1920-talet förkunna att just dessa företag hade gett Sverige en andra stormaktstid, nu inom vetenskap och näringsliv: "Våra tändstickor, kullager, telefoner och separatorer bära det svenska namnet på ryktets vingar, alldeles som förr våra segrar på slagfälten. Om vår namnkunnighet förr var begränsad till Norra Europa, är den nu universell." ${ }^{593}$

Under samma årtionde som De Geer d.y. gav uttryck åt sin nationella stolthet växte begreppet "snilleindustrin" fram. Till en början syftade uttrycket på den redan existerande framgångskulturen. Efter hand blev 
det emellertid också en mall i vilken bilden av nya industrier kunde formas. På så vis fördes myten om svensk snillrikhet vidare under 1930och 1940-talen av företag som Volvo och deras fordonstillverkning. ${ }^{594}$

Framställningarna av svenskhet, teknisk förmåga och entreprenörskap har med rätta beskrivits som på en gång repetitiva och föränderliga. Samtidigt som en standarduppsättning av namn och egenskaper återanvändes, växlade betoningen mellan den enskilde individen, företaget och konceptet entreprenörskap under perioder. ${ }^{595}$ Vad som dock var konstant var att de meningsbärande berättelserna fylldes med inslag av modernitet. Berättelserna om tekniknationen Sverige skrevs därför ofta fram parallellt med berättelsen om det nya samhället och dess löften om förbättrade livsvillkor. ${ }^{596}$ En given arena för sådana budskap var skolan. Som en upprepning av De Geers stolta förkunnelse under mellankrigstiden fylldes läroböcker i historia ett kvartssekel senare med texter där den svenska snilleindustrin framstod som en förutsättning för moderniseringens globala omfattning:

Nybyggaren på Sydamerikas pampas lagar sin mat på svenska primuskök, på floderna i Brasiliens urskogar surra svenska utombordsmotorer, indianen i México talar i svensk telefon, och lyxbilen som spinner fram på Italiens autostrador, rullar på svenska kullager. I så gott som hela världen finns det svenska tändstickor. Så bidraga svenskt uppfinnarsnille och svenskt precisionsarbete till att göra vårt land känt och aktat ute i världen. ${ }^{597}$

I den vetenskapshistoriska antologin Svensk snillrikhet? betonar författarna hur berättelserna om ingenjörsnationen Sverige hela tiden anpassades till sin samtid under 1900 -talet. ${ }^{598}$ Så skedde även under efterkrigstidens senare decennier, men då snarare som en erinran om något essentiellt som gått förlorat på vägen. I tidigare kapitel har jag framhållit att skolungdomars uteblivna tillströmning till naturvetenskap och teknik i slutet av 1960-talet och början av 1970-talet var en av orsakerna till att de tidigare så ljusa framtidsutsikterna förmörkades. Tillsammans med andra inslag under perioden - miljödebatten, industrikrisen och lågkonjunkturen - bidrog den till att successivt tona ned utvecklingsoptimismen i Sverige.

För arbetarrörelsen hade behovet av berättelser om tekniska snillen eller uppfinnarnationer varit förhållandevis begränsat under 1950- och 1960-talen. Rekordårens valmanifest, partiprogram och konferenser 
utmärktes inte av något omfattande historiebruk. Snarare var det teknikens och industrins villkor i framtidens samhälle som präglade den vetenskapliga offentlighet där Socialdemokraterna verkade tillsammans med aktörer som LO, näringslivet och forskningsberedningen. ${ }^{599}$

Men när partiet förlorade regeringsmakten i mitten av 1970-talet uppstod det ett behov av att blicka tillbaka på gångna decennier. Som oppositionsparti författade man en utförlig partimotion där en längre industriell framgång kopplades samman med välfärdssamhällets födelse:

Svensk teknik och svenska tekniker har länge haft ett gott internationellt anseende. Svenska produkter har hållit en hög kvalitet, och detta har utan tvivel varit en viktig förutsättning för våra framgångar på exportmarknaden. Detta har haft stor betydelse för vår goda ekonomi, vilken i sin tur lagt grunden för vår framgångsrika reformpolitik. ${ }^{600}$

Men för första gången på mycket länge var denna berättelse svårare att knyta till samtiden. Fler och fler tecken tydde snarare på formandet av en antites till bilden av en nation med speciell håg och fallenhet för naturvetenskap och teknik:

Vi har vant oss vid att betrakta det som något självklart att svensk teknik ligger i främsta ledet internationellt sett. Men tyvärr är det inte längre så självklart. Mycket tyder på att detta förhållande håller på att ändras och att vi på område efter område håller på att förlora vår ställning som ledande i fråga om teknisk kompetens. Ett flertal företagsledare och forskare har uttalat oro över en hotande teknologisk eftersläpning i Sverige. Om Sverige förlorar sin relativt sett överlägsna teknologi inom t. ex. den elektroniska industrin, verkstadsindustrin och stålindustrin är detta på sikt mycket allvarligt. Då kommer vi inte längre att ha samma grund som hittills för fortsatta samhällsförbättringar. I stället kan vår industri och därmed vårt samhälle komma att ställas inför stora svårigheter under kommande år. ${ }^{601}$

Vad partiet gav uttryck för var inledningen på en omförhandling av den nationella självbild som byggde på industriell entreprenörsanda, framgångsrik uppfinnarkultur och ett slags globalt tekniskt ledarskap. Till denna begynnande motbild fogades också "de senaste årens alltmer teknikfientliga klimat" som avspeglade sig i ungdomars attityder till 
naturvetenskap och teknik i skolan. ${ }^{602}$ Uppgifter av det slaget ökade avståndet mellan det förflutna och samtiden.

När rekryteringsproblemet visade sig kvarstå under de kommande decennierna bidrog det efter hand till formandet av en parallell berättelse om Sverige med allt starkare meningsproduktion. Vad som i förstone uppfattades som en anomali eller en tillfällig nedgång hade vid tidpunkten för Hässelbykonferensen 1993 antagit karaktären av en konstant i beskrivningen av allmänhetens relation till vetenskap. "Problemet är gammalt", kunde materialet inför konferensen berätta i en exposé över tidigare åtgärder. Översikten bidrog till att förmedla en historisk kontinuitet och ett frustrerande politiskt arv från tidigare decennier. ${ }^{603}$ Verket för högskoleservice visade i rapporten Naturvetenskap och teknik i Sverige indignation över att problemet kvarstod olöst:

I flera årtionden har ungdomar fått rådet att välja naturvetenskap och teknik för att få säker arbetsmöjlighet och intressanta uppgifter. Andelen flickor på området har hela tiden varit orimligt låg. Många insatser har gjorts för att nå fler flickor, särskilt under 70 -talet. En viss ökning har skett men den är inte stabil och under 80-talet har i perioder antalet flickor inom utbildningarna sjunkit igen. ${ }^{604}$

De historiska tillbakablickarna var således av två slag. För det första de som sträckte sig tillbaka till tiden före 1970 och som tecknade en samhällsutveckling och en välfärdsstat byggd på särskilda nationella förutsättningar inom teknik och industri. För det andra de som kunde visa upp en nyare och mindre smickrande tradition av nationell oförmåga att intressera sina yngre generationer för detsamma.

Tillsammans gjorde de båda berättelserna att samtiden i början av 1990-talet framstod som särskilt problematisk. I det perspektivet tycktes Sverige befinna sig längre ifrån sitt förflutna än många andra länder. Som en konsekvens fick de naturvetenskapliga och tekniska skolämnena en särdeles stark symbolisk funktion. De representerade områden som behövde återerövras - något som delvis kan förklara den snabba och omfattande politiska reaktion som karaktäriserade NOT-projektet. 


\section{"Antalet studerande i dessa ämnen är ändå otillräckligt”}

Under 1990-talet skulle det emellertid visa sig - i likhet med tidigare decennier - att utbildningsstatistiken efter hand inte kunde stödja bilden av naturvetenskap, teknik och ungdomars val som en renodlat problematisk kombination i Sverige. Den sjunkande antagningen till teknisk linje som åberopats i uppmarschen mot NOT-projektet följde snarare en allmän minskning av antalet femtonåringar under 1990-talets första år. I relativa tal hade antagningen till teknisk och naturvetenskaplig linje knappast minskat alls. ${ }^{605}$

I ett längre bakåtblickande perspektiv var det snarare uppenbart att studerande inom dessa utbildningar ökat kraftigt. Mellan mitten av 1950-talet och början av 1990-talet ökade det totala antalet ungdomar i landet som hade en teoretisk gymnasieutbildning inom naturvetenskap eller teknik från 4000 till närmare 20000 per år. De som avgick med civilingenjörsexamen från någon teknisk högskola var i början av 1960-talet cirka 800 personer årligen och hade 1990 stigit till 2600 . Bara under 1990-talets första år hade antalet helårsstudenter inom naturvetenskap och teknik vid universitet och högskolor ökat med 60 procent, en ökning som var större än för de övriga utbildningsområdena. ${ }^{606}$

Uppgången hade naturligtvis sin grund i efterkrigstidens allmänna utbildningsexplosion och den ökade tillströmningen till skolan och högre studier överlag. Men det faktum att naturvetenskap och teknik som utbildningsområde visade samma utveckling som de övriga sektorerna om inte bättre - gjorde det svårt att framhärda i att svenska elever under efterkrigstiden var allt mindre intresserade av dessa ämnen. Dessutom hade de framgångsrika kampanjerna med basåret och N/T-SVUX bättrat på statistiken ytterligare.

Därför blev det också problematiskt att berättiga nya satsningar utifrån en problembeskrivning som talade om att "vända trender". När NOT-projektet gavs ett förnyat uppdrag 1998 motiverades arbetet på ett delvis annat sätt. I presentationerna av uppdraget framkom att antalet utbildningsplatser i naturvetenskap och teknik periodvis hade ökat ännu snabbare än antalet studenter i ämnena. Betraktat i det perspektivet var det snarare regeringen som förstärkt sin egen problembeskrivning om tomma stolar i laborationssalarna. ${ }^{607}$

Korrigeringen av bilden påverkade dock inte rekryteringspolitikens 
fortsatta riktning eller legitimitet. En talande formulering från Utbildningsdepartementet löd: "Intresset [för naturvetenskap och teknik] har också ökat hos studerande på alla nivåer i utbildningssystemet. Antalet studerande i dessa ämnen är ändå otillräckligt.”'008 Som en konsekvens startades nya projekt upp medan gamla fortlöpte i en strävan att fylla samtliga utbildningsplatser. Därtill skulle behovsbilden kontinuerligt hämta näring ur internationella sammanhang, som successivt ökat sin betydelse. Till dessa vänder vi oss nu.

\section{Rekryteringspolitik bortom nationalstaten}

I Kristianstad anordnades 1996 för femte gången ”Nordiska forskarsymposiet om undervisning i naturvetenskap i skolan". Arrangörerna formulerade sina utgångspunkter för evenemanget genom att blicka in i nästkommande årtusende: "Vi står nu inför en viktig satsning att utveckla undervisning i naturvetenskap på olika nivåer för att kunna tillmötesgå 2000-talets krav på att höja såväl den allmänna kunskapsnivån i naturvetenskap och teknik som att tillfredsställa näringslivets behov av kvalificerad arbetskraft." ${ }^{09}$ Sammankomsten gav således uttryck för den vid det här laget väl inarbetade symbiosen mellan rekryteringspolitik och naturvetenskaplig didaktik. Öppningsanförandet hölls av statssekreteraren i Utbildningsdepartementet Carl Lindberg, som kunde knyta an till en tidigare yrkesidentitet som naturvetare. Denna gång representerade han dock den svenska regeringens starka intresse i frågan. Från talarstolen kunde han bland annat meddela åhörarna regeringens ambitioner att inom kort utöka högskoleväsendet med 30 ooo platser och att minst hälften av dessa var vikta för naturvetenskap och teknik. ${ }^{610}$

Även andra talare i Kristianstad berörde den svenska rekryteringsfrågan. Bland dessa fanns högskolans rektor, Claes I. Helgesson. Han underströk den betydelse som didaktisk utveckling spelade i grundskolan och i gymnasiet:

Utan förståelse för de naturvetenskapliga fenomenen blir det för barn och ungdomar svårt att förstå naturvetenskapens och teknikens roll i samhällsutvecklingen - och, som vi sett under många år, svårt att locka ungdomar till tekniska och naturvetenskapliga yrken. Det har sagts många gånger men förtjänar att upprepas: utan tillgång till personal med kvalificerad teknisk och naturvetenskaplig utbildning står 
sig svensk industri och det svenska samhället i övrigt slätt i den allt hårdnande internationella konkurrensen. ${ }^{611}$

Trots att nationella förväntningshorisonter dominerade inramningen vid forskarmötet, bedömdes perspektivet vara meningsfullt även för de deltagare som kom från övriga Norden. Det hade delvis sin grund i att rekryteringen till naturvetenskap och teknik blivit mer uppmärksammad som ett problem även i dessa länder. ${ }^{612}$ När Nordiska ministerrådet senare förde samman statsråden inom forskning och utbildning i Norge, Sverige, Finland och Danmark (med Island), formades meningsproduktionen av perspektiv som främst utgick från de fem grannländernas intressesfärer. Jämförelser sinsemellan innebar att varje nation betraktades i ljuset av de andras tillkortakommanden och förtjänster, samtidigt som problemet kunde ses som gemensamt för den nordiska kultursfären. ${ }^{613}$

Den nordiska förståelsen av problemet underströk att rekryteringsfrågan hade en nationsöverskridande karaktär. En berättelse som i diskursivt avseende var betydligt mer kraftfull var den som anlade europeiska perspektiv på unga människors förhållande till naturvetenskap och teknik. En mer enad europeisk kontinent var en återkommande tankefigur vars rötter bland annat sträckte sig tillbaka till Wienkongressen under 1800-talet och den så kallade Paneuropeiska unionen på kristen grund under mellankrigstiden. ${ }^{614}$ När idén om en gemensam identitetsformering återkom efter andra världskriget vilade den i retoriskt avseende starkt på fredstanken och återuppbyggandet av den krigshärjade kontinenten. Som jag visade i kapitel 2 spelade ekonomiska och produktionsmässiga motiv tidigt stor roll för den betydelse utbildning inom naturvetenskap och teknik tillmättes i arbetet. OECD hade med projektet "New Thinking in School Science" sökt förändra undervisningen till både innehåll och form. Initiativet stannade dock på policystadiet och när kampanjen var över minskade de europeiska greppen över naturvetenskap och skola. Under de följande decennierna skulle sådana idéer mer anta karaktären av en underström. ${ }^{615}$

När Europeiska unionen bildades 1993 bekräftade det en vilja att återigen förstärka Europatanken, inte minst på bärande områden som ekonomi, lagstiftning och utbildning. I relation till det sistnämnda drevs Europakommissionen av en strävan att främja "den europeiska dimensionen" inom skolor och akademier. Med stora program - Erasmus, Sokrates, Comenius - sökte den bland annat minska skillnaderna mellan ländernas olika utbildningssystem. ${ }^{.16}$ 
Som en konsekvens av denna utveckling genomfördes under 1990-talet en kraftig europeisering av naturvetenskaplig och teknisk utbildning. Ambitionerna tog sig delvis uttryck i en generell strävan att öka den vetenskapliga allmänbildningen och förståelsen för forskning. ${ }^{617} \mathrm{Men}$ därutöver hade målsättningen mycket tydliga rekryteringspolitiska inslag. I rapporten Europe Needs More Scientists uppskattade EU behovet till 500000 nya personer inom dessa utbildningar fram till 2010. Den gemensamt skisserade problembilden gjorde det möjligt med ett samordnat informationsinhämtande. Flera länder visade upp en låg andel yrkesverksamma inom naturvetenskap och teknik. Sverige tillhörde dock inte dessa. Tvärtom ansågs landet tillsammans med Danmark och Finland visa på föredömligt höga nivåer, till skillnad från de södra och mellersta delarna av unionen. ${ }^{618}$

Ändå tonades de regionala skillnaderna ned i många formuleringar och istället renodlades en identitet som byggde på ett bredare narrativ. På så sätt blev alla länder en del av problemet och dess lösning. "Europe must overcome the problem of 'intelligence fatigue', the slowing down of knowledge creation. To do this, we must bring science to life in classrooms, laboratories and the boardrooms of private and public science organisations." ${ }^{619}$ Vikten av att sluta upp runt ett gemensamt problem inskärptes av formuleringar som talade om ett unikt europeiskt särdrag, manifesterat av motsättningen mellan upplysningens rationella vetenskapstro och romantikens hyllande av naturen, känslorna och intuitionen. Arvet efter romantiken, menade Europakommissionen i sin rapport, hade levt kvar trots det moderna samhällets framväxt. Det kunde bland annat märkas i olika typer av motståndskulturer mot vetenskap bland den europeiska allmänheten. ${ }^{620}$

Försöken att skriva fram kollektiva identiteter gjorde det möjligt att diskutera utformningen av rekryteringsåtgärder på unionsnivå. Precis som i Sverige ledde resonemanget till att olika målgrupper identifierades för styre mot naturvetenskap och teknik:

As the number of students in Europe is quite high, it may be possible for the whole of Europe to catch up with the much larger percentage of R\&D workers per 1000 workforce in the US and Japan or northern parts of Europe. For that to happen, it is necessary to attract more youngsters to the science and engineering area by acting on the undecided cohorts who enter universities, by providing them with attractive 
science courses in the first years. The fact that the first year in university is considered in some countries as a selection point associated with tough teaching may be a cause for désaffection. It may be relatively easy to correct this situation by making lectures and practical classes more attractive $[\ldots]^{621}$

Att ringa in problemet i dessa internationella sammanhang skapade förutsättningar för en befolkningspolitik i betydligt mer omfattande skala. När NOT-projektet knöts till större nordiska och europeiska motsvarigheter utökade detta möjligheterna till att vidta mer omfattande åtgärder. ${ }^{622}$ Norden och Europa var två nationsöverskridande enheter som båda underströk den dubbla meningsproduktion vilken kringgärdade försöken att få fler ungdomar att söka sig till naturvetenskap och teknik. Å ena sidan betonades jämförelser och konkurrens, å andra sidan samarbete och gemensamma problemhorisonter. Det blev också uppenbart ur en global synvinkel. Samtidigt som det europeiska perspektivet på rekryteringsfrågan förstärkte EU:s gränser mot de viktigaste konkurrenterna USA och Japan - framförallt när det gällde ekonomisk utveckling och arbetsmarknad - var det inte ovanligt att ungdomars attityder till vetenskap infogades i bilden av de tre världsekonomiernas gemensamma problemhorisonter. Elevernas ointresse framställdes ofta som typiskt för västerlandet eller de post-industriella samhällena, där en särskild sorts skepsis och avståndstagande i perioder antogs ha präglat yngre generationers förhållningssätt. ${ }^{623}$

\section{Naturvetenskap och skolungdom som transnationellt värde}

En bidragande förklaring till varför rekryteringspolitiken i slutet av 1900-talet återigen så tydligt kommit att överskrida nationalstaten som diskursiv gräns, kan sökas i den utbredda existensen av flera typer av system för jämförelser. På ett antal globala arenor hade uppgifter om utbildning och kunskaper i naturvetenskap och teknik börjat få karaktären av ett slags symboliskt kapital länder emellan och ett mått på framgång för en stat, en union eller en ekonomi. Jag kommer nedan att identifiera tre arenor som successivt bidrog till att förstärka komplexet vetenskap och skolungdom som transnationellt värde och som på olika sätt möjliggjorde etablerandet av plattformar eller visuella system för jämförelser. 
Ett första sådant sammanhang var beräkningar av antalet utbildade ingenjörer och naturvetare i varje land, något som möjliggjordes genom OECD:s Frascatimanual redan under tidig efterkrigstid. När mätningarna hade standardiserats på 1960-talet gav detta organisationen ett slags ensamrätt över bedömningskriterierna, liknande den position som National Science Foundation hade etablerat i USA under samma period. Manualerna har reviderats under decennierna men deras normerande funktion har bestått. När den svenska industrin i början av 1990-talet talade om tävlan och konkurrens på exportmarknaden var det på OECD:s mätningar den baserade sig. Slutsatserna i texter som Ingenjörsvetenskapsakademiens Ingenjörer inför 200o-talet återgavs senare i det underlag som låg till grund för NOT-projektets formande. Där återkom också 1950-talets resonemang om att ingenjörstäthet var en viktig faktor i skattningen av ett lands konkurrenskraft. En högre andel examinerade tekniker och naturvetare inom befolkningen bedömdes ge den sammanlagda arbetskraften en större kompetens och kunna öka produktiviteten. ${ }^{624}$

En andra nationsöverskridande arena utgjordes av internationella sammanställningar av skolelevers prestationer och attityder till naturvetenskap och matematik. Det omfattande arbetet inom forskningsorganisationen IEA, som under svensk ledning genomförts och presenterats i början av 1970-talet, hade under de efterföljande decennierna antagit allt större proportioner. Andra generationens studier, SISS (Second International Science Study), presenterades 1988 och tredje generationens, TIMSS, (Third International Mathematics and Science Study) ett årtionde senare. ${ }^{625}$

De omfattande studierna gav alltmer raffinerade möjligheter att skapa tydliga hierarkier och rangordna olika utbildningssystem, inte minst i relation till begreppet "kunskapsekonomi" (knowledge economy). Lanseringen av humankapitalteorin under det tidiga 1960-talet hade förordat investeringar i utbildning. Mätningarna från IEA gjorde det möjligt för länder att jämföra sig även när det gällde utfallet eller "avkastningen" av sina satsningar, manifesterade i elevers prestationer. Den med tiden alltmer globala omfattningen påskyndades ytterligare vid ingången till 2000-talet när OECD lanserade en egen mätningsform i de så kallade PISA-studierna (Programme for International Student Assessment). På relativt kort tid skulle dessa två system få stort inflytande över hur länder utformade sin utbildningspolitik. ${ }^{626}$

Ytterligare ett uttryck för det transnationella värde som utbildning inom naturvetenskap och teknik tillerkänns, var den snabbt ökande 
marknaden för vetenskapliga ungdomstävlingar. Jag har tidigare nämnt de två äldsta och mest prestigefyllda varianterna - National Science Fair och International Science Olympiads. I motsats till breda statistiska kunskapsmätningar som TIMSS och PISA var det här fråga om jämförelser baserade på ett relativt litet antal högpresterande individer. Vad som väglett dessa arrangemang och skänkt dem en växande legitimitet är för det första ett grundläggande antagande om naturvetenskapernas universella och gränslösa karaktär - något som möjliggjort tanken om ett tävlande på rättvisa villkor. För det andra består populariteten i att deltagarna på ett individuellt plan lockas med ekonomiska belöningar, berömmelse och vetenskapliga kontakter. Därtill har tävlingarnas upplägg med intåg under nationsfanor, prisutdelningar och medaljceremonier skapat en situation där de utvalda eleverna inte bara representerar sig själva. Genom sina prestationer understryker de också kvaliteten på sitt hemlands utbildningssystem med dess läroplaner, lärarkår och förmåga att fostra vetenskapliga eliter. ${ }^{627}$

Vid 1990-talets mitt hade dessa tävlingar fått erkännanden av global omfattning. Såväl formerna som antalet deltagare har växt undan för undan. Tack vare sponsorer som multinationella företag (Intel Corporation) och världsomspännande organisationer (Unesco) har evenemangen också legitimerats som värdefulla tillfällen för sociala och kulturella utbyten mellan deltagarna. I kölvattnet av dessa tävlingar har en stor mängd andra arrangemang av liknande slag etablerat sig. De bekräftar alla naturvetenskap, teknik och utbildning som ett alltmer utbrett symboliskt kapital, både på individuell och nationell nivå. ${ }^{628}$

I detta kapitel har jag behandlat den allt större omfattningen av teknisk och naturvetenskaplig rekryteringspolitik i slutet av 1900-talet, både på globala arenor och i Sverige. Hässelbykonferensen och NOT-projektet var utslag av en nationell kraftsamling mot ett problem som vid tidpunkten framförallt betraktades som ett hot mot den inhemska industrins möjlighet att hävda sig på internationella marknader. Fler och bättre utbildade ingenjörer och naturvetare ansågs behövas på de flesta nivåer inom samhället för att klara konkurrensen med utlandet. Identifierandet av specifika målgrupper - "PNT-elever" - ingick i det speciella vetande om problemet som ackumulerades under perioden. Sådana målgrupper eller publiker var en administrativ innovation samtidigt som de ingick i ett tidigare mönster där speciella kategorier eller "reserver" för naturvetenskapliga och tekniska studier prospekterades som meningsfulla för 
ett rekryteringspolitiskt tilltal. Flickor fortsatte även under denna period att vara en särskild sorts "PNT-elever" inom den större behovsbilden.

Samtidigt som kapitlet tydligt skrivit fram de internationella perspektiven har även de nationella föreställningarna skärskådats för att visa på den särpräglade självbild som Sverige levt med under stora delar av 1900-talet, och som även gjorde sig gällande vid seklets slut. En sådan identitet har länge dominerats av teknik, industri och vetenskapliga genier - ett arv som i ljuset av rekryteringsproblematiken blivit alltmer betungande att blicka tillbaka på.

Många av de åtgärder som vidtogs under 1990-talet, däribland basåret och N/T-SVUX, understödde bilden av naturvetenskap och teknik som särskilt förknippade med valfrihet och ökade möjligheter för den enskilde. Kampanjerna handlade för det första om en bredare behörighet till utbildningssamhället och kunde retoriskt knyta an till den aura av exklusivitet som i decennier omgett den naturvetenskapliga "kungsleden". För det andra förmedlade de budskapet att teknik och naturvetenskap var frigörande $\mathrm{i}$ en vidare mening som berörde mer allmänna livsvillkor och identiteter som samhällsmedborgare, kvinna eller klassresenär. I det sammanhanget betonades värden som sysselsättning, karriär och meningsfullhet på ett sätt som bidrog till att göra investeringen i utbildningarna mer konkret. 